a Irena Seidlerová (*1926) - působily na Matematicko-fyzikální fakultě; Seidlerová se provdala za významného matematika Miroslava Katětova (1918-1995), který se stal rektorem Univerzity Karlovy v pětatřiceti letech.

Za kapitoly o doktorkách matematiky na Německé univerzitě v Praze a na Univerzitě Karlově zařadila autorka užitečný statistický přehled vyplývající z tématu, statistické údaje jsou zařazeny také do úvodu. Ve sledovaném údobí bylo na Univerzitě Karlově uděleno celkem 150 doktorátů z matematických oborů, na Německé univerzitě 39. Německá univerzita měla podstatně méně posluchačủ než Univerzita Karlova, ale právě matematika byla její silnou stránkou - také pisatelé disertací brali na moderní trendy v matematice větší ohled než jejich čeští kolegové. Její absolventi, z nichž mnozí byli židovského původu, se uplatnili na prestižních univerzitách USA a západní Evropy. Menšinová Německá univerzita prožívala tehdy př́znivé časy také díky tolerantní politice prvorepublikových vlád, které se vůči ní chovaly jako ke státní univerzitě a finančně ji nijak neomezovaly - v meziválečné Evropě neměl takový př́ípad obdoby.

Kniha Martiny Bečvářové je strhující četba. Autorka své téma pojala v širokých odborných i společenských souvislostech. Podařilo se jí shromáždit neuvěřitelné množství údajů z nejrůznějších zdrojů nejen o samotných protagonistkách, ale též o jejich rodinných příslušnících. Někteří z nich byli významnými osobnostmi ve vědě, školství, kultuře, technice, jiní hráli důležitou roli v rámci regionů. Zvláště zajímavé jsou detailní pasáže nejen o průběhu rigorózních zkoušek, ale také o státních zkouškách pro kandidáty učitelství a maturitních zkouškách. O pečlivé heuristické práci svědčí 633 poznámek, z velké části obsáhlých. Monografii zhodnocuje i podrobné anglické resumé čítající 33 stran. Čtenář, který se celý život profesionálně věnoval humanitním oborům, cítí určitou lítost, že matematiku opomíjel.

Marie Štemberková doi: $10.14712 / 23365730.2020 .11$

\title{
Juraj Šebesta, Zakladatel slovenskej fyziky. Život a dielo Dionýza llkoviča
} Bratislava 2019, 478 s., ISBN 978-80-227-4879-7

Pohledů do vývoje slovenské vědy není k dispozici př́liš mnoho, proto vždy potěší, když se objeví nová publikace na toto téma. Juraj Šebesta je historik fyziky, emeritní vědecký pracovník Fakulty matematiky, fyziky a informatiky Univerzity Komenského v Bratislavě a rovněž bývalý zástupce Slovenska v Mezinárodní unii pro dějiny a filozofii vědy a techniky (IUHPST/DHST).

Jeho monografie o životě a díle Dionýze Ilkoviče není jen př́iběhem jednoho člověka, ale odráží i vývoj slovenské vědy a zejména slovenských vědeckých institucí v průběhu 20. století, vypovídá však mnohé i o české a československé vědě. Dionýz Ilkovič se narodil v roce 1907 v Šarišském Štiavniku v rodině ortodoxního duchovního. Autor podrobně rozebírá i původ rodinného př́ijmení a kořeny rodiny v minulých stoletích. Dionýz pak vystudoval reálné gymnázium v Prešově a odešel na pražskou Českou vysokou školu technickou. Z ní však brzy přestoupil na pražskou Přírodovědeckou fakultu UK, kde svá studia úspěšně absolvoval. Navázal blízkou spolupráci se svým profesorem Jaroslavem 
Heyrovským, s nímž se též podílel na počátku třicátých let na rozpracování polarografických metod. Jejich spolupráce šla tak daleko, že později - zejména po roce 1959, kdy Heyrovský dostal Nobelovu cenu za chemii - se v literatuře objevovala obvinění, že Heyrovský Ilkovičovi ukradl některé postupy a přivlastnil si zásluhy o polarografii jen pro sebe. Šebesta $\mathrm{v}$ rámci své knihy tyto záležitosti podrobně rozebírá a na základě analýzy archivních pramenů obvinění vyvrací.

Ilkovič dále působil mezi lety 1930-1940 v Praze jako středoškolský profesor. Absolvoval také několik studijních zahraničních pobytů. Nikdy ale nepřerušil kontakt s Přírodovědeckou fakultou, kde těsně před vypuknutím 2 . světové války zahájil habilitační rízení. Nestihl je však dokončit kvůli uzavření českých vysokých škol po 17. listopadu 1939. Dokončil je až po válce a v Praze dosáhl docentury, kterou tam už pak nikdy neuvedl v život. V roce 1940 byl mezitím povolán do Bratislavy, kde po celou válku přednášel na Univerzitě Komenského a na Slovenskej vysokej škole technickej. Tam byl jmenován profesorem technické fyziky a vedle toho zároveň i profesorem fyziky na Prírodovedeckej fakulte Slovenskej univerzity v Bratislavě. Už toto dvojí jmenování ve stejnou dobu trochu naznačuje personální situaci při obsazování vědeckých a vysokoškolských pozic na Slovensku v tomto období. V prrípadě Ilkoviče to pokračovalo i po válce, takže čtenář může mít místy dojem, že fyzika na Slovensku od 40. do 60. let byl př́běh jednoho muže.

Na počátku padesátých let se Dionýz Ilkovič podílel na vzniku Slovenskej akadémie vied a stal se i jejím členem-korespondentem. Právě v padesátých letech se nejvíce prohýbal pod tíhou mnoha vědeckých funkcí i pedagogických úvazků, což se podepsalo na jeho zdraví. Od šedesátých let již musel své aktivity trochu utlumit. Přesto zůstal v aktivní službě až do druhé poloviny sedmdesátých let minulého století. Zemřel v Bratislavě v roce 1980.

Jeho život a působení jsou ukázkou zvratů a peripetií, kterými prošlo Slovensko a slovenské vědecké instituce od druhého desetiletí 20 . století do období normalizace. Pro českého čtenáře je asi nejzajímavější popis situace na Slovensku v průběhu 2. světové války, kdy byly české vysoké školy uzavřené. Slovenské vysoké školství a slovenské vědecké instituce naopak zažívaly rozkvět, a to takový, že právě v tomto období (1942) byla založena Slovenská akadémia vied a umení, která byla spolu s Maticí slovenskou centrální vědeckou institucí v zemi před založením Slovenskej akadéme vied v roce 1952. Zajímavé jsou v Šebestově knize i postřehy o setkávání se slovenské, německé a italské vědecké obce v období 2 . světové války, které byly tehdy i po válce posuzovány zcela jinak než u českých vědců, žijících v Protektorátu.

Životopis Dionýza Ilkoviče je v knize zpracován velmi podrobně, do detailů, které si autor mohl dovolit díky tomu, že prostudoval kvanta dostupných archivních materiálů v českých i slovenských archivech. Získal i dokumenty, uložené v rodinném archivu Ilkovičových a jeho dcery Dagmar Havlové (manželky Ivana M. Havla), díky čemuž předestřel opravdu hluboký a pestrý vhled ho fyzikova života. Vzhledem k rozsahu práce se některé úryvky opakují, protože výpovědní hodnota nastudovaných písemností je pochopitelně rozdílná. Obecněji je třeba uvést, že v práci jsou citovány četné pasáže z úřední i ze soukromé korespondence a z dalších archiválií, které jsou pospojovány autorovými výklady a komentáŕi. Pro českého historika vědy jsou velmi cenné zejména všechny poznatky k životu a dílu Jaroslava Heyrovského a k poměrům na vysokých školách v Praze ve dvacátých a třicátých letech. 
Rozsáhlému rukopisu se samozřejmě nevyhnuly některé nesrovnalosti. Pro nás je např̀. nezvyklé použivání zkratky PF pro Př́rodovědeckou fakultu UK, protože takto se zpravidla označuje Právnická fakulta, př́rodovědu bychom zkracovali PřF UK. Jmenný rejstř́ik je v knize poněkud nedotažený, u některých jmen zcela chybějí odkazy na stránky, kde jsou zmíněna. Na s. 74 narazíme na špatné číslování poznámek.

Kniha je opatřena celou řadou fotografických i popisných př́loh. Samostatnou kapitolkou - patř́icí též spíše do oblasti př́loh, proto zmíněna zde - jsou historky o Dionýzu Ilkovičovi, které autor sesbíral od jeho kolegů a studentů. Velmi cenný je přehled všech přednášek a seminářů, které si nejprve Ilkovič v Praze zapsal jako student, a poté i těch, které v Praze i v Bratislavě vedl jako pedagog.

Milada Sekyrková

doi: $10.14712 / 23365730.2020 .12$

\section{Petr Feldstein - Tomáš Libánek, Skoro proti všem. Časopis Student v nejslavnější éře československé žurnalistiky \\ Grada Publishing, Praha 2019, 255 s., ISBN 978-80-247-2861-2}

Vydávání novin kriticky naladěných vůči komunistickému režimu je badatelsky atraktivním a společensky významným tématem. Při jeho zpracování rozkrývají historikové a zástupci jiných společenskovědních oborů okolnosti, za kterých daná periodika vznikala, čím se zabývala, kolik si dokázala získat čtenářu a jaký osud je potkal po okupaci Československa vojsky Varšavské smlouvy.

Nedílnou součástí takového výzkumu jsou dramatické životní příběhy vydavatelů. Někteř́ byli v šedesátých letech představiteli dospívající mladé generace a chtěli v novinářské profesi uplatnit svoje schopnosti a vydobýt si společenské uznání. Jejich snaha psát o konkrétních společenských problémech originálně, poutavě a zároveň co nejvěcněji se výrazně prolínala se sférou politickou.

Výše uvedené aspekty se týkají časopisu Student, který vycházel od října 1965 do konce srpna 1968. Tento týdeník si zvolil za téma své diplomní práce historik Tomáš Libánek. V roce 2007 ji obhájil. Poté ji spolu s Petrem Feldsteinem - pamětníkem a redaktorem - upravil tak, aby mohla vyjít knižně. Výsledek jejich spoluautorství je podle mého názoru zdařilý.

Oba čtivě a s kritickým odstupem zpracovali téma, jemuž dosud nebyla $v$ historiografii věnována pozornost. Zužitkovali různorodé prameny z Národního archivu, Archivu bezpečnostních složek a z dobových časopisů. Chvályhodné je rovněž to, že Libánek natočil rozhovory s redaktory Studenta a do textu je zapracoval. Hojně citované Feldsteinovy vzpomínky mají ve vyprávění nezastupitelnou úlohu a dodávají mu svěžest.

V této souvislosti si však dovolím podotknout, že autoři v seznamu zdrojů a literatury uvedli neexistující Archiv Úřadu pro studium totalitních režimů. V lednu 1995 vznikl Úřad dokumentace a vyšetřování zločinů komunismu (ÚDV) a od roku 2007 funguje Ústav pro studium totalitních režimů (ÚSTR) spolu s Archivem bezpečnostních složek (ABS). Také se domnívám, že kvůli lepší orientaci by ve výčtu archivních dokumentů neměly chybět 